\title{
Mobility nodes and economic spaces: Links, tensions and planning implications
}

\author{
Redento B. Recio \\ University of Melbourne \\ redento.recio@unimelb.edu.au
}

\author{
Iderlina Mateo-Babiano \\ University of Melbourne \\ imateo@unimelb.edu.au
}

\section{Sonia Roitman \\ University of Queensland \\ s.roitman@uq.edu.au}

\begin{abstract}
While transport hubs function largely as mobility interchanges, they also serve as spaces of conflict and negotiation, particularly when informal livelihoods of poor populations take place in public spaces like streets and transport terminals. This condition poses challenges to urban planners and transport officials on how to promote inclusive cities without sacrificing urban mobility. We examine how informal trading has become embedded in the land-use patterns of Baclaran, a strategic transport hub in Metro Manila. Three factors emerge as critical in understanding how and why informal trading thrives in Baclaran: a) the presence of commuters as captive market; b) mixed land use and activity agglomeration; and c) multi-layered socio-spatial relations. Our empirical data also shows how normalized informal trading in a mobility node has triggered transport route diversion and supported the growth of small-scale informal transport.
\end{abstract}

\section{Article history:}

Received: October 23, 2018

Received in revised form:

July 31, 2019

Accepted: October 4, 2019

Available online: November 4, 2019

\section{Introduction}

Many drivers have long avoided driving on that [Baclaran] street... because of the presence of street vendors... Vendors have exacerbated the traffic congestion. (Mike, ${ }^{1}$ a jeepney ${ }^{2}$ driver) If you stop vendors from selling on sidewalks, it is tantamount to killing them. They sell to earn a living...They get their food from vending. (Myra, a commercial stallholder) We have policies [against vending] but we do not implement them. [We realized], when there's no livelihood [opportunity], the crime rate goes up. There's a lot of hold-up and housebreak incidents... (Allen, a local government official)

The foregoing statements represent the opinions of some stakeholders on street vending in Baclaran, one of the largest informal trading districts in the Philippines. To an extent, these views resonate with some dilemmas, as will be explained later in this article, that policymakers in many global South cities face when they regulate street vending. As they promote efficient urban mobility, they also need

\footnotetext{
${ }^{1}$ All the names that appear in this paper are pseudonyms we use to protect the interviewees' identity.

${ }^{2}$ Jeepney, a public utility vehicle in the Philippines, originated from surplus USA military jeeps after the World War II.
}

Copyright 2019 Redento B. Recio, Sonia Roitman, \& Iderlina Mateo-Babiano

ISSN: $1938-7849$ | Licensed under the Creative Commons Attribution - Noncommercial License 4.0

The Journal of Transport and Land Use is the official journal of the World Society for Transport and Land Use (WSTLUR) and is published and sponsored by the University of Minnesota Center for Transportation Studies. 
to grapple with unemployment and poverty, which drive poor populations to embrace informal livelihoods. A potential approach to this puzzle is an inclusive land-use plan addressing the issues that emerge when informal trading intersects with transport activities in public spaces. Yet, as we will show in the subsequent sections, decisionmakers need to consider several factors before they can craft a transit-oriented and inclusive land-use plan. In this paper, we ask: What are the factors that sustain informal vending in transport hubs? How does informal vending affect urban transport nodes and land-use patterns?

Metro Manila offers key lessons that speak to the issues and questions above. Home to almost 13 million residents (PSA, 2015), Metro Manila has been the Philippines' primary urban region since the Spanish colonial period in the late 16th century. It has attracted rural migrants looking for better economic opportunities. In many cases, these migrants engage in urban informal vending in transport nodes like terminals, bus stations and parking areas. In this paper, we analyse the factors that sustain informal trading and how the latter impacts on the transport sector. We focus on Metro Manila's Baclaran district, a strategic urban node where informal vendors have been selling street merchandise since the 1950s.

Our paper offers three key contributions to transport and land-use research, specifically within the global South context. First, its qualitative analysis illustrates how the confluence of mixed land use and urban socio-spatial relations (Sections 4.1, 4.2 and 4.3) has normalized informal trading in a transport hub. Second, it demonstrates how transport actors could suffer or benefit from the congestion generated by informal trading in mobility nodes (Sections 5.1 and 5.2). Third, the paper shows how unpacking the trading-transport interface affirms the need for a post-dualist view in understanding how informal vending thrives in a "formally" designated transport node. As we will explain below, a post-dualist view offers a way to examine the congested spaces occupied by informal vendors beyond the prisms of locational utility, spatial mismatch and urban "disfunctionalities." It urges urban scholars to investigate how the interplay between "formal" and "informal" spaces influences the flows and interconnections between economic activities, land-use patterns, and transport issues in many global South cities.

Following this introduction, we present a literature review on street vending, urban transport, and land-use concerns before explaining the conceptual framework used in examining the qualitative data. We then discuss the research methology and situate the case study area in the larger Metro Manila's socio-spatial arrangements. After this, we explain the factors that have sustained street vending in Baclaran, and how it affects the land-use patterns and the transport sector in the area. In the last section, we discuss the implications of the identified factors for designing plans to manage street vending in transport nodes like Baclaran.

\section{Street vending, transport and land use in the Global South}

In developing Asian countries, over $50 \%$ of urban labour force is engaged in informal economy ${ }^{3}-81 \%$ in South Asia and 65\% in East and Southeast Asia (Vanek, Chen, Carr, Heintz, \& Hussmanns, 2014). Within the urban informal employment, street vending is seen as the most visible livelihood (Brown \& Mackie, 2017). Yet, there are no accurate statistics on the volume of informal street vendors. Informal trading activities are not included in official planning documents; they are "off the map" (Robinson, 2006). In the Philippines, where $75 \%$ of the labour force works in the informal economy (World Bank, 2013), street vending is generally prohibited in public spaces.

Public spaces such as streets and sidewalks are places where social relations and rights are constantly redefined, negotiated, and contested (Mitchell, 2003; Meneses-Reyes \& Caballero-Juarez, 2014). As

${ }^{3}$ Informal economy refers to the units, activities, workers in and outputs from employment without social protection as well as unincorporated enterprises that may also be unregistered and/or small (Vanek et al., 2014). 
such, occupying public spaces entails collaborative and conflictive relationships arising from different rights (Meneses-Reyes \& Caballero-Juarez, 2014; Bostic, Kim, \& Valenzuela, 2016). For instance, the right to use streets for work and for mobility might contradict each other. Urban policies affecting street use are thus seen as ways of "arranging spatial exclusion and inclusion" (Davy, 2009, p. 231).

Recognizing this complex nature of public spaces is important in understanding street vending, a worldwide phenomenon that requires governance intervention (Bostic et al., 2016). Street vending involves people who provide goods or services for sale in public spaces like streets and pavements. The vendors may be stationary or mobile, carrying their wares on push carts or in baskets (Bhowmik, 2005). In many cities, vendors are considered citizens with rights (Meneses-Reyes \& Caraballo-Juarez, 2014) whose economic initiatives contribute to urban employment (UN-Habitat, 2009; Roever \& Skinner, 2016) and the vibrancy of civic life and public spaces (Bostic et al., 2016).

As vendors engage in economic initiatives, they also form social capital, which reduces their vulnerability to police harassment, conflicts with other space users, and socio-spatial exclusion (Moser \& Lister, 1999). In many instances, however, social capital is insufficient to endure repeated evictions, which are seen as a solution to the bottlenecks generated by informal vending in congested streets, major intersections, and bus terminals (Cervero, 2013; Bostic et al., 2016). The literature shows how eviction has reduced vendors' income, disrupted their social networks (Donovan, 2008; Carrieri \& Murta, 2011) and caused health issues arising from psycho-social trauma and economic distress (Brown, 2006). In some cases, eviction has led to deaths of resisting vendors (Okello, 2017) due to violent confrontations with state authorities.

Many governments also resort to a relocation strategy, which has yielded mixed results. On the one hand, there are a few cases where local governments have successfully resettled hawking activities without conflict by involving vendors in the negotiation process (Bunnell, Miller, Phelps, \& Taylor, 2013; Phelps, Bunnell, Miller, \& Taylor, 2014; Song, 2016). On the other hand, several studies reveal that vendors return to their previous spaces due to ill-conceived new locations, bureaucratic and costly regulations, and the lack of customer drawing power of the chosen locations (Bromley 2000; Donovan, 2008; Weng \& Kim, 2016). When the eviction-relocation approach fails, the state-vendor relationship is often characterized by conflict and/or negotiation.

This uncertain condition has prompted vendors to occupy public spaces through spontaneous and planned encroachments (Bayat, 1997; Musoni, 2010), varied forms of resistance (Swider, 2015; Flock \& Breitung, 2016), and tenuous ties with street-level bureaucrats (Peña, 1999; Recio, 2015; Swider, 2015). In short, street vending thrives in contested public spaces amidst adverse policy environment or changing political conditions. In some cities, the entrepreneurial activities associated with street vending even increase land value and generate new spatial relations (Oriard, 2015), affecting land use and transport activities.

Indeed, there is a close link between trading and transport as many vendors rely on high pedestrian flows located near busy streets and passenger terminals. It is therefore crucial to situate the tradingtransport nexus in the broader transport and land-use discourse. The literature has acknowledged the transport and land use or TLU relationship (Banister, 2008; Acheampong \& Silva, 2015; Duffhues \& Bertolini, 2016), which is conceptualised as a transport-land use feedback cycle (Duffhues \& Bertolini, 2016) and land use and transportation interaction (Acheampong \& Silva, 2015). However, there is difficulty in isolating and measuring the mechanisms through which transport and land use affect each other since other socio-spatial forces such as demographic, economic and policy issues shape how the two systems operate (Lundqvist, 2003; Wegener, 2004; Acheampong \& Silva, 2015). There is also a need to examine how social issues and political realities shape land-use patterns and transport (Waddell, 2011). On a more pragmatic level, attentiveness to socio-political relations helps address the institutional barriers to the implementation of plans for transport and land use integration (UN Habitat, 2009; Duffhues 
\& Bertolini, 2016).

Given these considerations, our paper seeks to enrich the TLU literature by explaining how some spatio-political factors that reinforce the trading-transport nexus are embedded in state-designed landuse plans and informal practices on the ground. We also emphasize the broader social and planning implications of these factors and discuss the impacts of informal trading on certain transport stakeholders.

Based on the conceptual and empirical insights presented in the previous section, we employ a post-dualist approach (Recio, Mateo-Babiano, \& Roitman, 2017; Recio, 2018) to analyse how urban informality issues like street vending are linked to transport and land use. A post-dualist framing builds on an enmeshed reading of informality issues, evident in the work of Roy (2005), Yiftachel (2006), Donovan (2008), Porter (2011), and Dovey (2012). Besides these urbanists, earlier writers also pointed out that the "formal" and "informal" sectors are not mutually exclusive; they are intricately related (Stavenhagen, 1965) and interlaced (McGee, 1973) as the manufacture and flow of goods are generated in both sectors. A post-dualist lens views urban informality as part of a system of norms governing the process of urban transformation itself (Roy \& AlSayyad, 2004). It is never situated outside formal systems, "but is instead produced by formal structures and always intimately related to them" (Porter, 2011, p. 116). In other words, we see informal economic activities as inherently linked to formal and state-regulated transactions.

With this framing of urban informality, our analysis moves beyond looking at the congested spaces occupied by informal vendors as outcomes of locational utility (Janelle, 1969), spatial mismatch ${ }^{4}$ (Duffhues \& Bertolini, 2016), and urban agglomeration or "disfunctionalities" (Scott \& Storper, 2015). We contend that examining economic spaces, land-use patterns, and transport issues requires paying attention to the wider social context and the layered spatio-political relations in the "formal" and "informal" structures of power. Our discussion in Section 4 shows the importance of this analytical vantage point. In what follows, we present the methods used in generating and analysing qualitative data.

\section{Research methodology and case study area}

Previous studies on informality have revealed how examining "informal" livelihoods is fraught with empirical nuances that elude neat methodological approaches (Bunnell \& Harris, 2012). Even data collection may involve ethical concerns as many street vendors thrive on learned habits that evade the state's watchful gaze. Although this poses research dilemmas to urban scholars who want to amplify the voices of marginalised groups, academic work can be a potent way to represent (Bunnell \& Harris, 2012) and articulate issues that are often muted in the government's cost-benefit calculations. Given these considerations, we used multiple data collection methods to capture the complex conditions and issues surrounding informal vending, transport and land-use patterns.

The empirical findings are a product of a qualitative research utilizing document review, focus group discussions or FGDs (20 participants), life histories (seven vendors), in-depth interviews (75 respondents), and repeated site observations (undertaken between February 2015 and February 2017). Collated documents include national laws, local ordinances, government programs, plans, and agreements relevant to informal vending and street use. Three FGDs were undertaken to consider the views of vendors who were not part of the interviews. FGD participants, who were identified through a snowball approach, comprised the following: 1) organized vendors; 2) unorganized vendors with varied religious affiliations; and 3) unorganized Muslim vendors. We identified and invited these participants

\footnotetext{
${ }^{4}$ Urban intensification refers to people's intense use of space arising from "an increase in activities accessed by both inhabitants and visitors" (Duffhues \& Bertolini, 2016, p. 17). Mismatch happens when "land-use planning is directed at intensification while transportation planning is directed at speeding up and extending networks..." (Duffhues \& Bertolini, 2016, p. 18).
} 
after learning from vendor leaders and barangay officials that organized and unorganized vendors have divergent views on issues in Baclaran. It was also crucial to get the Muslim perspectives as local officials claimed that their numbers have continued to rise and they have issues different from Christian hawkers.

Meanwhile, life histories involved seven vendors-five women and two men, with different backgrounds and who were part of the initial interviews focusing on problems in Baclaran streets. Their narratives helped us better understand the vendors' daily activities, space use, problem-solving strategies, and arrangements with other stakeholders to occupy the streets. With respect to interviews, we divided the participants into clusters pertaining to their institutional mandate and views on street use. The clusters included the following: a) national government officials (12 respondents); b) local government officials (15 respondents); c) members and leaders of organized vendors (11 respondents); d) unorganized vendors (11 respondents); e) NGO leaders (three respondents); f) individuals representing the private sector including jeepney drivers (13 respondents); and g) academics and development workers (ten respondents).

Figure 1 below illustrates the process we followed to identify and select the respondents for the interviews, FGDs and life-history. We started with a purposive sampling where we focused on 1) the government agencies involved in transport and street vending; 2) the vendor organizations in Baclaran and Metro Manila; and 3) academics who have studied transport and informal vending issues.

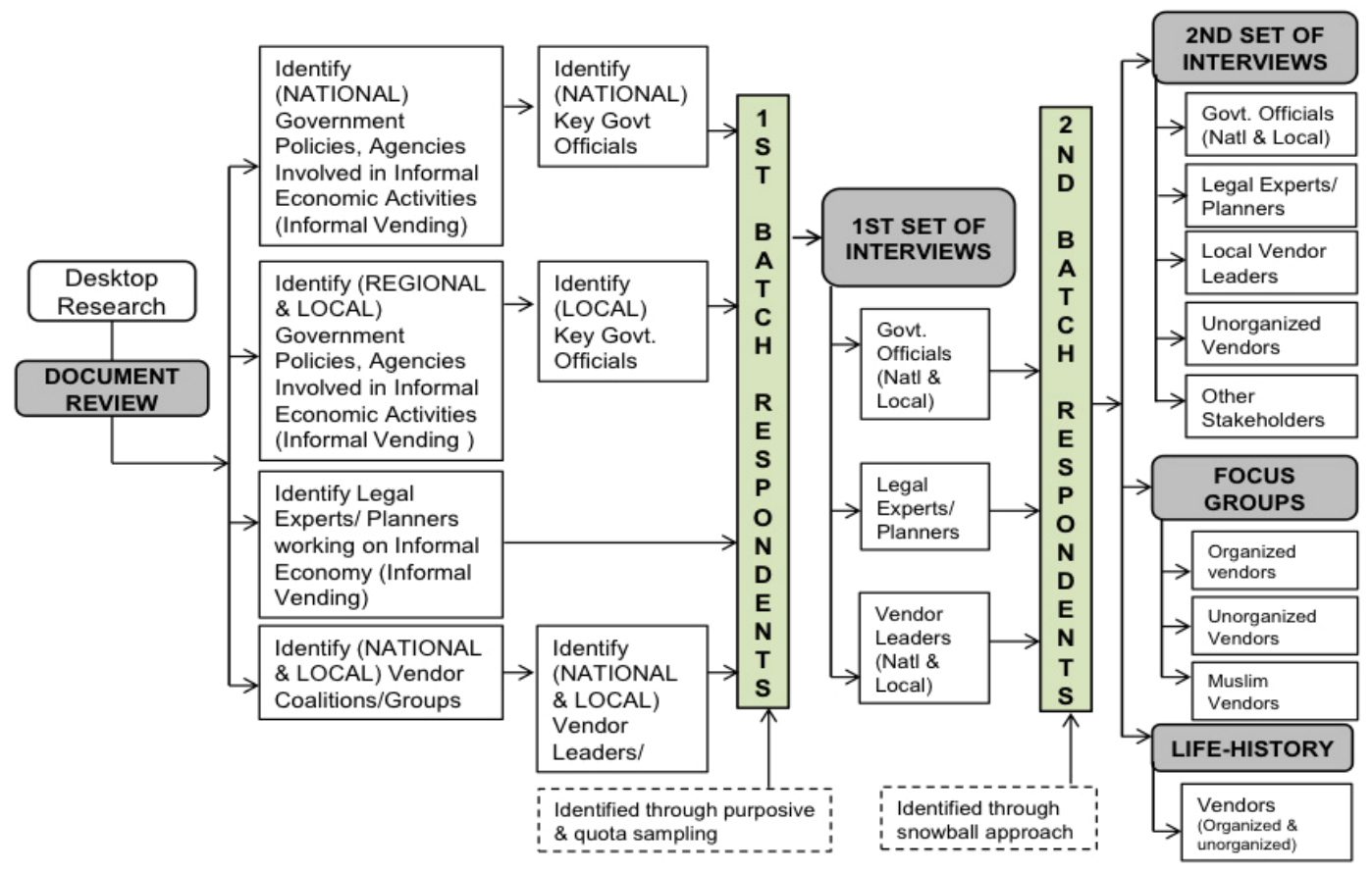

Figure 1. Respondent selection flowchart

Based on the list of agencies and organisations, we identified the agency heads or organizational leaders as part of the first set of interviewees. These respondents then served as sources for contacting a new set of participants via snowball sampling. The list of names identified by the first set of interviewees and who agreed to take part in the research constituted the second batch of interviewees. A series of agency visits and conversations with officials was conducted. As much as possible we kept a balance regarding the interviewees' gender, duration of involvement in street hawking and affiliation with a vending organisation.

The quotes that appear in this paper represent analytical threads emerging from the respondents' statements. We used the Nvivo software in coding, categorizing, and examining the collected data. Some 
themes we examined for this paper included: a) vendors' collective action; b) conflicts and tensions between different players; and c) street vending impacts on other sectors. As data coding and analysis continued, new themes were added such as land-use plan, street use and spatial dimension of trading. After clustering the themes, data coding centered on the threads emerging from the document review and life-history accounts. The clustered themes were compared against the results of other data collection methods. The last stage of coding and analysis focused on the information gathered through observation and another round of interviews to validate the initially examined data and to seek further explanation on the emerging themes. It was also in this final phase when we analyzed the patterns, nuances, and issues in the previously determined threads.

In investigating the relationship of informal trading to transport and land use, we focus on Baclaran, one of the largest urban informal hawking areas in the Philippines. Baclaran borders Pasay and Parañaque, two component cities of Metro Manila (see Figure 2). In this paper, Baclaran refers to the area occupied by informal vendors, which covers one barangay ${ }^{5}$ in Parañaque and five barangays in Pasay.

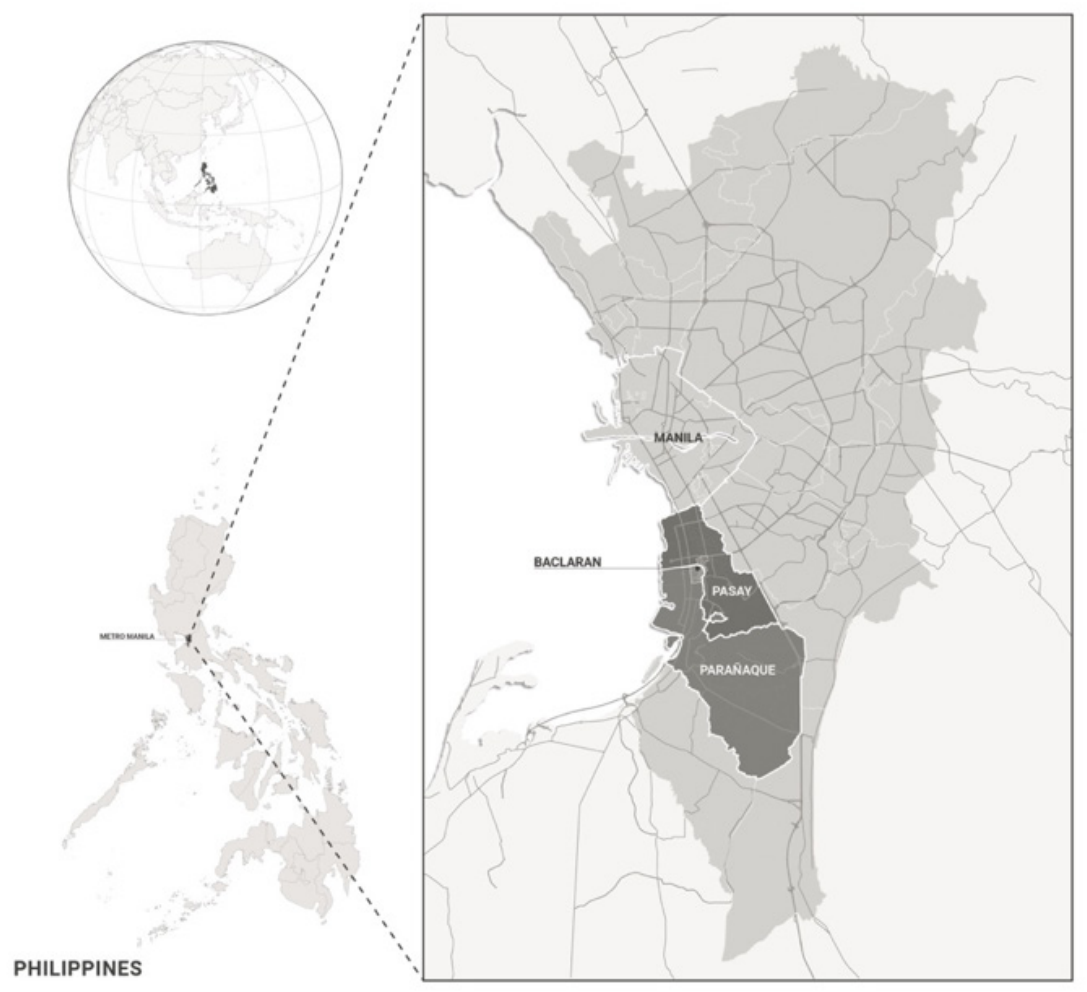

Source: Redento Recio

Figure 2. Baclaran borders Pasay and Parañaque cities in Metro Manila

Pasay's and Parańaque's zoning maps designate Baclaran district as a commercial area. A series of site observations, however, showed that Baclaran is home to establishments with diverse functions. Figure 3 illustrates the different activities in Baclaran: transport, commercial, residential, and socio-cultural functions.

As reflected in Figure 3, one of these functions pertains to religious practices. The Baclaran Church

\footnotetext{
${ }^{5}$ Barangay is the smallest political-geographical unit in the Philippines. It has formal village-level government structure with elected executive and legislative officials.
} 
(a popular Filipino Catholic devotional site), two other Christian structures and three Muslim mosques are located in Baclaran. This presence of religious establishments near manufacturing and commercial centers is one of Baclaran's unique features. As a commercial district, Baclaran welcomes shoppers who want to buy affordable products like shoes, handbags, clothes, household accessories and school supplies.

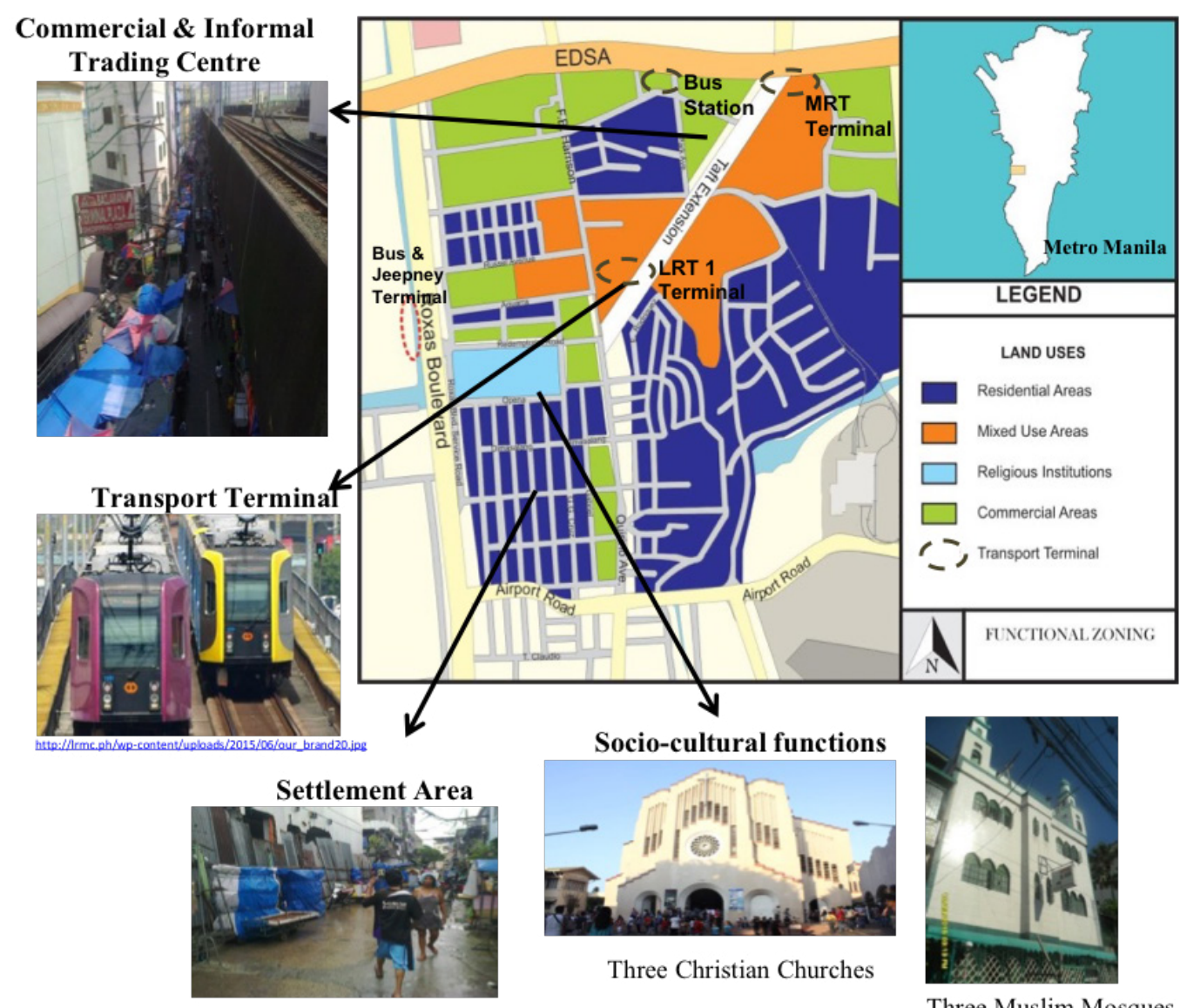

Figure 3. Baclaran as a strategic space for multiple activities ${ }^{6}$

In terms of its relationship to Metro Manila's spatial order, Baclaran was already a metropolis transport hub even before the construction of shopping malls in the 1990s. There were bus terminals for people travelling to nearby cities and provinces. In 1984, the completion of the Baclaran Light Rail Transit (LRT) terminal attracted more people to the area. Baclaran is also close to three of Metro Manilas radial and circumferential roads, which connect the metropolitan's component cities to the surrounding provinces. In what follows, we present the empirical evidence on the links and tensions between street vending, transport and land use.

\section{$4 \quad$ Why street vending thrives in transport nodes: Research findings}

The literature has demonstrated how informal vending adds to congestion on streets and in transport terminals (Cervero, 2013). While this also occurs in Baclaran, we have identified other factors that showcase the links and tensions between street vending, transport and land use. These are 1) the pres-

\footnotetext{
${ }^{6}$ All photos in this paper are taken by Redento Recio.
} 
ence of commuters as vendors' captive market; 2) mixed land use and activity agglomeration; and 3) the multi-layered socio-spatial relations. We argue that decision-makers and urban planners should pay attention to these factors in designing inclusive transport and land-use plans. As explained in Section 2, we take a post-dualist approach in examining these factors. This post-dualist prism allows us to frame how street hawking has capitalized on the formally inscribed land-use plans and commercial activities. Street vending has also altered previously designated public vehicle route and has encouraged the growth of small-scale informal transport, illustrating how the trading-transport nexus enhances the functional mix and the formal-informal interface in many urban centers.

\subsection{Pedestrians and commuters as captive market}

One of Baclaran's main features is its densely-occupied streets and transport terminals, a key factor why vendors have chosen it as a livelihood space.

Every Sunday, Saturday and Wednesday, many people go to the [Baclaran] Church. Then, there are those who buy garment products ... There are also bus terminals. Actually, more people started coming here after this [Baclaran LRT terminal] was constructed in the early 1980s (Chris, a vendor leader)

Chris' observation is substantiated by information from other sources. The Baclaran LRT station alone had a monthly average of approximately two million commuters in $2014 .^{7}$ In the same year, the nearby MRT3 EDSA Terminal had over 2.4 million monthly passengers (DOTC, 2015). Additionally, Baclaran Church has around 120,000 devotees every Wednesday.

The surrounding areas - hotels, factories, shopping centers, provincial bus terminals—also attract pedestrians and commuters. This confluence of socio-spatial factors depicts the nature of transport terminals and socio-cultural establishments as "natural markets" (Bhowmik, 2010) where street vendors take advantage of the presence of many commuters and devotees as a captive market.

Different estimates of the current number of Baclaran vendors abound. Local officials say there are 1000-3000. Vendor leaders estimate that there are 1500-2000. Our repeated calculations using a digital tally counter indicate that there are over 1500 semi-fixed stalls and ambulant hawkers during ordinary days and almost 4000 on peak days (Wednesday, Saturday, Sunday) and during the Bermonths ${ }^{9}$ (September-December). Vendors put up semi-fixed kiosks or roam around four Baclaran road networks:Taft Avenue Extension, Harrison-Quirino Avenue, Redemptorist Road, and Roxas Boulevard Service Road.

\footnotetext{
${ }^{7}$ The actual monthly average is 1, 992,102 passengers (DOTC, 2015).

${ }^{8}$ Natural markets "spring up in places where the consumers find them useful. Hence there will be street vendors outside railway stations and bus depots" (Bhowmik, 2010, p. 13), as people returning from work would rather purchase their needs from these vendors than go to markets situated several kilometres away.

${ }^{9}$ On ordinary days, vendors earn between PhP 100.00 (US \$2.17) and PhP 500.00 (US \$10.9). On peak days, their average income is over PhP 500.00 a day; a few of them earn around PhP 3,000.00 (US \$65.22). Bermonths, a period beginning in September until December, is a peak season for vendors when shoppers flock to Baclaran to buy affordable goods in preparation for Christman and New Year celebrations.
} 
They sell items including clothes, shoes, housewares, toys, gadgets, fresh fruits and vegetables (see Figure 4).
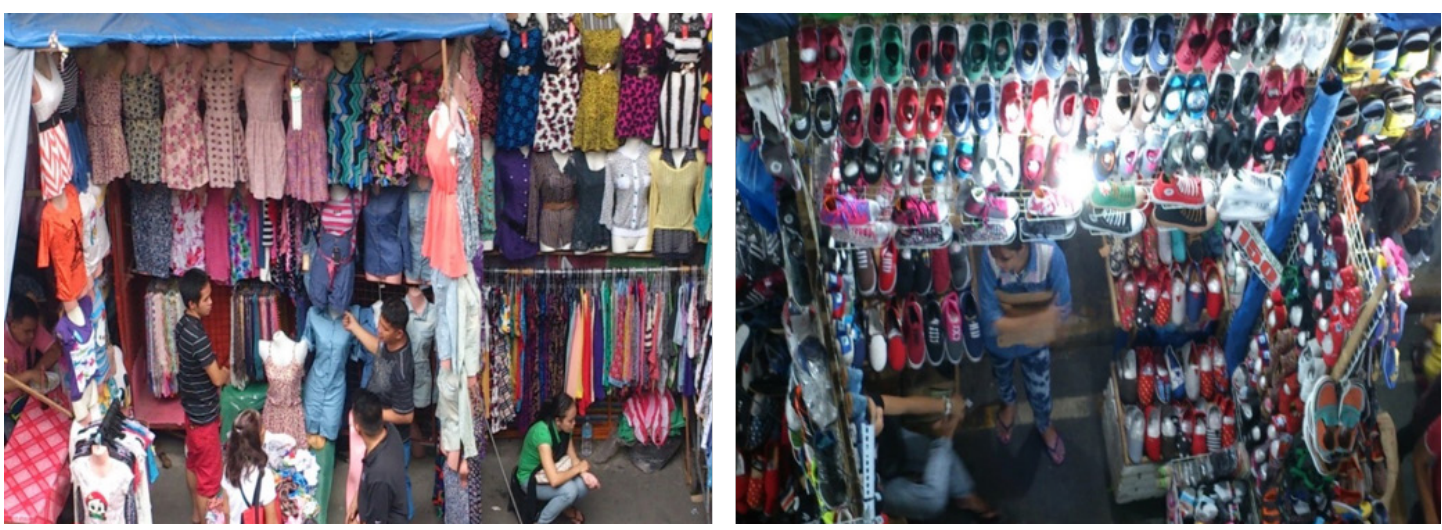

Figure 4. Baclaran street products

\subsection{Mixed land use and agglomeration}

Baclaran's mixed land use plays an important role for street vendors. Besides being a transport node (as noted in Section 4.1), Baclaran is home to commercial warehouses of formal stallholders in the nearby shopping malls. Vendors get their supplies from these warehouses when they run out of stocks. Further, many street hawkers live in the nearby residential areas, allowing them to save on transport cost when they need to go home and get some rest. Their relatives are also there to help them manage the vending stalls. Kaye, a city official, explained how it happened in Pasay. "They [vendors] were not originally from Pasay. They just decided to settle in our communities because they have gotten used to it; they have ended up looking for dwelling spaces nearby." It is also common to see relatives of vendors sleeping at or playing (in the case of children) around their hawking spaces. This indicates how vending areas have become an extension of dwelling spaces for some hawkers.

Moreover, some smaller interior streets, which are not used for vending, serve as storage or parking spaces for vending carts. We call these spaces secondary streets in relation to vending activity. They support the vibrant interaction of different users on the primary streets, which are crowded with vehicles, pedestrians and street vendors. Secondary streets also function as safe spaces where hawkers run to when eviction occurs.

Finally, the mosques in Baclaran are important for Muslim street hawkers. They are not only sacred sites; they also enable vendors to interact with community leaders and discuss vending-related issues with fellow hawkers. In this sense, mosques act as a contact zone where hawkers get to share their everyday sentiments and strengthen their social capital.

To summarise, Baclaran's mixed land use comprises four intersecting functions: 1) transport node; 2) commercial center; 3) residential area; and 4) socio-cultural site. Street hawkers have capitalized on this agglomeration of activities, making it part of their daily lives and socio-cultural interactions. Baclaran's situation thus demonstrates that urban agglomeration-a mechanism of sharing, matching and learning ${ }^{10}$ —involves an interface between what are often demarcated as "formal" and "informal" economic transactions. The overlapping activities also resonate with how Dovey (2016) views urban dis-

\footnotetext{
${ }^{10}$ Scott and Storper (2015) define sharing as the dense local inter-linkages within production systems. They refer to matching as the process of pairing people and jobs, and learning as "the dense formal and informal information flows..." (Scott \& Storper, 2015, p. 6)
} 
tricts like Baclaran as a place of functional mix - a site for living, working and visiting. The relations and flows between these different functions enhance Baclaran's "urban mix" and appeal to both the consumers and sellers of street merchandise. The empirical account illustrates how informal trading has become embedded in Baclaran's mixed land use as it co-produces new functions and interconnections. It is never insulated from the wider socio-spatial relations in the area, which are presented next.

\subsection{Multi-layered socio-spatial relations}

Political ties enable many vendors to gain access to Baclaran streets. In one Baclaran zone, for instance, political operators and ward leaders assisted evicted Muslim residents, who used to occupy a reclaimed area in Parañaque's "entertainment city" 11 to resettle in Parañaque and Pasay communities. "We got in touch with Muslim leaders and helped them register as barangay residents in Pasay," narrated Jess, an organizer for local politicians. This assistance forged a relationship between political organizers and Muslim leaders who have capitalized on their increasing population as an electoral leverage with politicians vying for government positions. Armed with this political influence, the Muslim leaders have gained concessions from local government officials, including access to vending spaces for Muslim residents. As a city bureaucrat named Kaye emphasized, "Right now, they [some city officials] circumvent the laws just to accommodate them [vendors]. Therefore, they [vendors] become more confident to "squat" on the streets."

In Parañaque, there is another way of dealing with vendors: local officials distinguish between the "illegal ambulant hawkers" and the "legitimate vendors." As Andy, a barangay official, clarified, "The illegal vendors - those we call ambulant occupy any vacant space... [I]f there is clearing operation they just run.... The legitimate [vendors] are those who inherit [the hawking spaces] from their parents, [who] were the old vendors before." Another local official, Allen, added, "When we say legitimate, they are those who were already on the streets when our former Barangay Chair came to power... We call them "legitimate," rather than legal, because they are just there without necessarily being legal...They are vendors who have been on the streets for a long time." The local officials tolerate the presence of "legitimate" vendors and segregate them from the ambulant hawkers whom they can evict anytime.

This selective acceptance reflects a socio-spatial hierarchy in policy enforcement-a phenomenon where access to contested urban spaces is layered and insecure, spatially uneven, and temporally rhythmic. In this situation, "exclusion is not absolute, but rising barriers require strategies and resources" (Flock \& Breitung, 2016, p. 166). In Baclaran, this manifests in the spatial arrangement of vending stalls. While those who have semi-fixed kiosks - the organized and politically connected vendors-occupy the streets with high pedestrian flows (e.g, LRT-Baclaran station, see Figure 5), the ambulant vendors (see Figure 6) inhabit the residual spaces that are prone to government clearing operations. As

${ }^{11}$ This is part of the Bay City mega-project, a mixed-use agglomeration of new residential and commercial centers located in reclaimed coastal areas in Manila, Parañaque and Pasay. 
noted above, local officials consider the duration of occupancy a key factor in classifying what constitutes "legitimate" and "illegal."

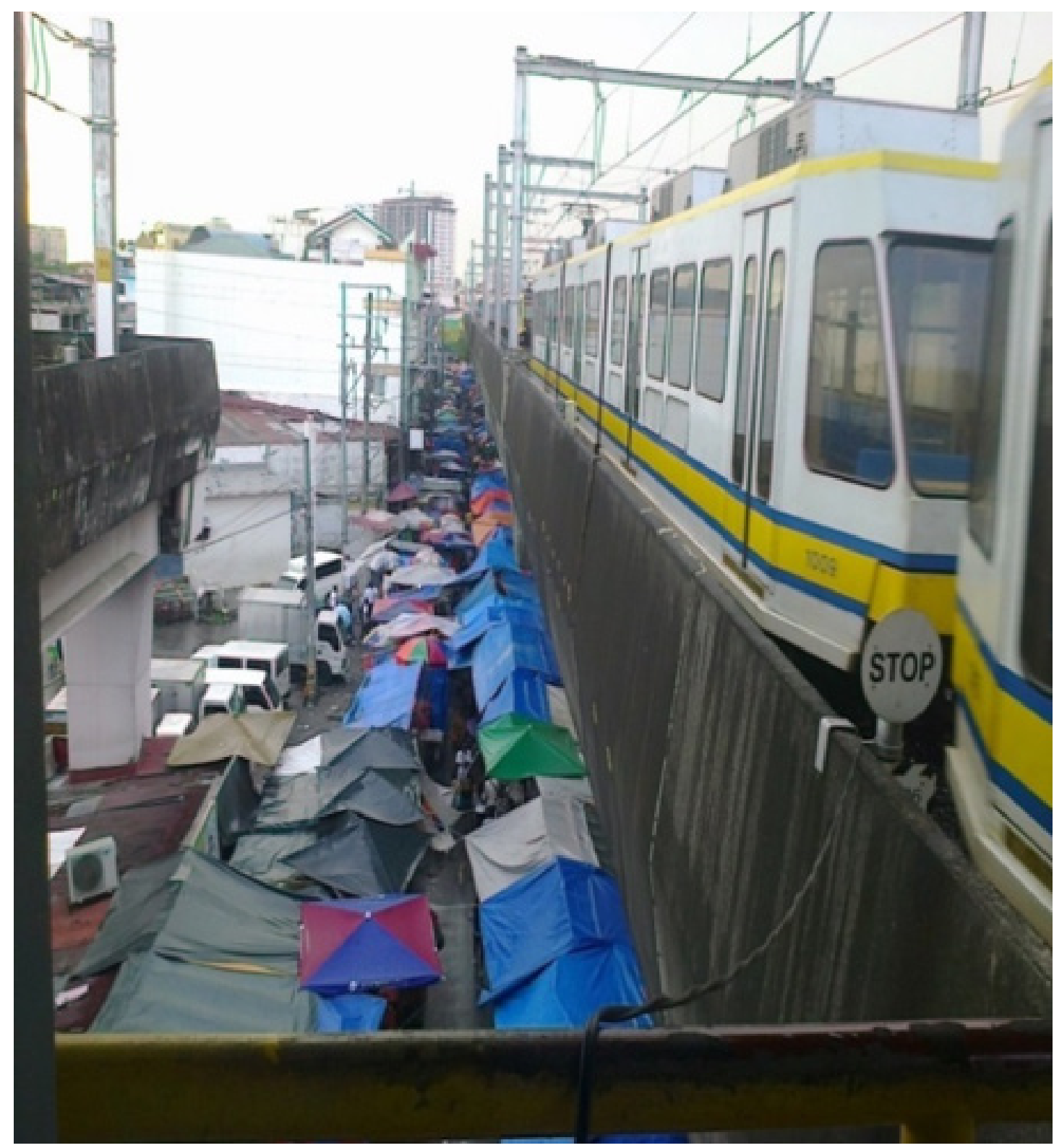

Figure 5. Vendors under the LRT1 rail track on Taft Avenue extension 


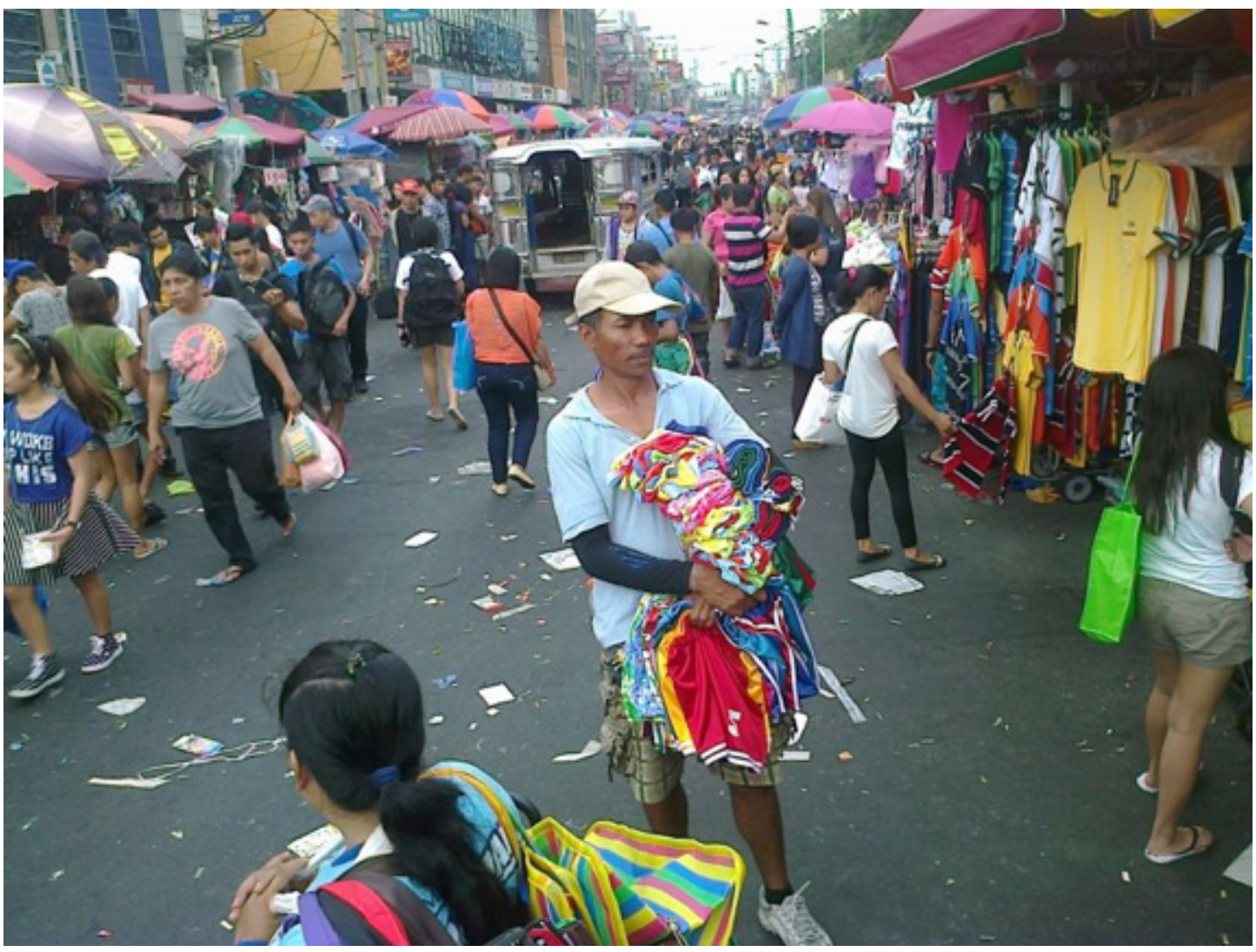

Figure 6. Ambulant hawkers on Redemptorist Road

Moreover, some of those who have secure locations encroach on the available spaces: "It is better to occupy this [sidewalk] space. This will be invaded by street hawkers, anyway," Nancy, a formal stallholder, admitted. Some organized street vendors with semi-fixed stalls also expand their stalls or put up new kiosks on vacant spaces. As stallholders and vendors try to outmanoeuvre each other, their street presence has adversely affected jeepney drivers who feel politically powerless in the struggle for limited space. As driver Alejo lamented, "Even if we go to the City Hall, nothing would change. It's like talking to the wind." In the end, the drivers simply followed a city government's order to alter their route to ease the congestion in the area occupied by vendors.

The empirical insights above underscore the need to go beyond the spatial and economic dimensions of urban agglomeration and informality. The socio-spatial hierarchy in policy enforcement demands an attention to the links between economic transactions and political relations in an urban environment. As seen above, while informal vendors are "embedded in networks of personal relations with economic as well as non-economic aims" (Granovetter, 1992), they also cling on to tenuous political relations that afford them access to contested spaces. Some of them even gain a level of legitimacy. These embedding processes offer conceptual and empirical insights that go beyond what urban agglomeration and intensification provide. We therefore argue that planners and policymakers should examine how the use of contested urban spaces is determined by social relations as well as political interests. This partly explains why informal vending persists in mobility nodes, generating certain conditions that affect the transport sector. 


\section{Effects of street vending on the transport sector}

In the subsequent paragraphs, we explain how informal vending has affected the transport sector in two ways - it has led to public transport route diversion and encouraged the growth of indigenous transport.

\subsection{Public transport route diversion}

Metro Manila suffers from severe traffic congestion due to the increasing number of vehicles and the limited investment in large-scale public transport facilities (Pacheco-Raguz, 2010). In the absence of affordable and efficient mass transport, many commuters rely on small transport units. The jeepney is arguably the Philippines' most popular small-scale public transport (see Figure 7). It can load 18 to 22 passengers.

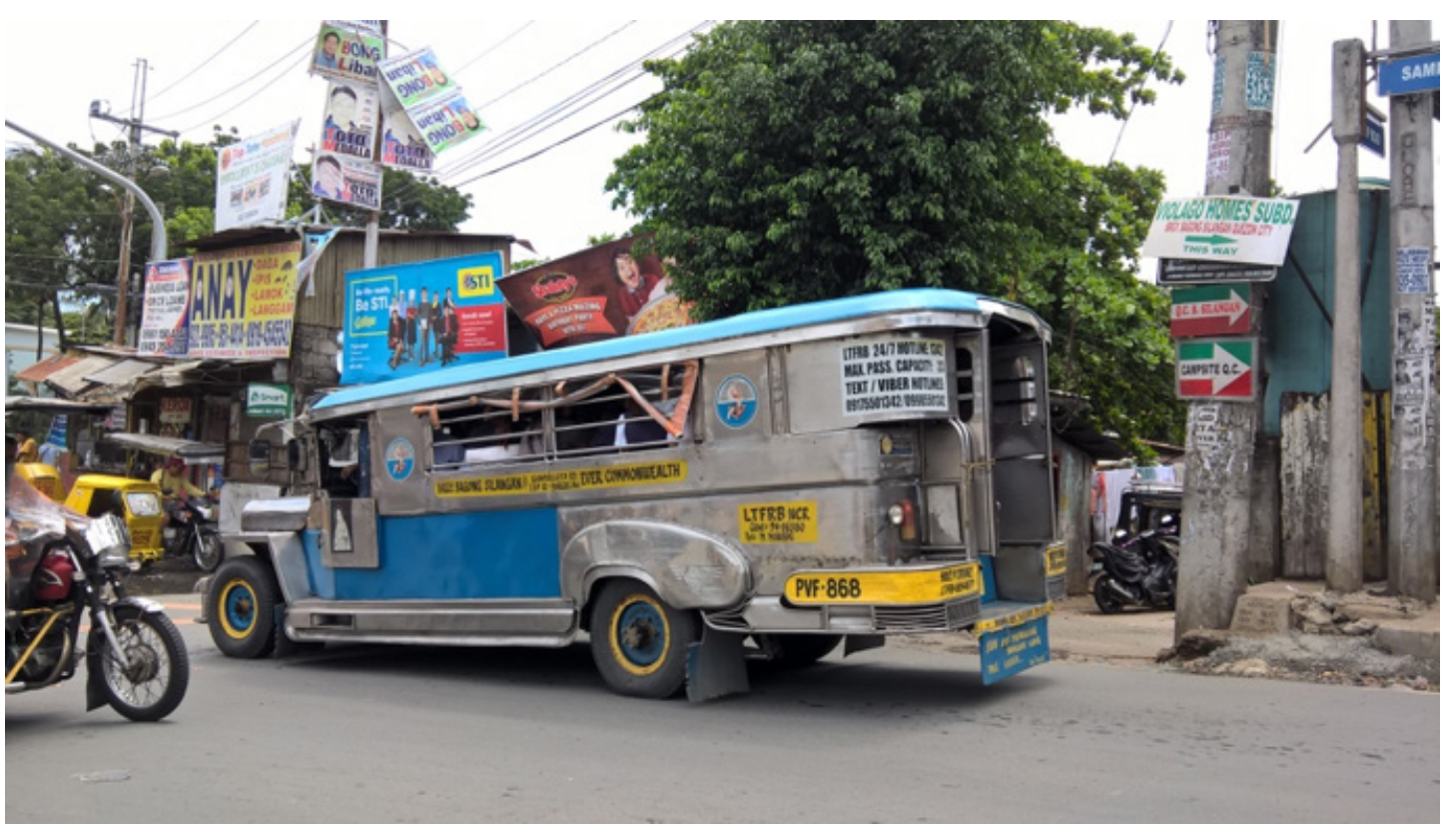

Figure 7. Jeepney is considered king of the road in many Philippine cities

In Baclaran, jeepneys used to pass through the Baclaran LRT station. "Before, we were able to reach that point [Baclaran LRT station]. Now, it's hard to get through that area because of vendors. If you hit their products, they would gang up on you," a jeepney driver named Alejo explained. Ambulant hawker, Eugene, admitted that street vendors find ways to get rid of jeepneys: "When they [jeepneys] come near [our vending stalls], some hawkers puncture their [jeepney] tyres using nails."

As mentioned in Section 4.3, some drivers have altered their routes following a city government order to divert their endpoint to ease congestion in Baclaran streets. However, Boyeth, a driver for two decades, cited two reasons why there is a constant traffic problem in Baclaran: "It's [because of] the cars parked [near shopping malls]...and the [presence of] many vendors." This ability of hawkers to alter public transport channels echoes Oriard's (2015) argument on how vendors are able to produce a space where streets become attractive and vibrant marketplaces.

The "jeepney route diversion" has also affected commuters. As Alejo shared, "They [passengers] also complain. [They say], "we have to hail a jeepney at that area [Tomas-Claudio], then take another ride here [at Pasay] ... It [route diversion] costs PhP5.00 (US\$ 0.1) from that area [Tomas Claudio] and another PhP5.00 from this point." Despite these adverse effects, jeepney drivers have not collectively 
challenged the local government directive instructing them to alter their regular route because they feel powerless to contest the order.

The foregoing narrative illustrates the conflictive socio-spatial interactions involving jeepney drivers and street vendors. The drivers' sentiments indicate how they feel marginalized in the scramble for contested spaces.

\subsection{Reinforcing the presence of indigenous transport}

Similar to other global South cities, Metro Manila is home to informal or "indigenous transport" (Mateo-Babiano, 2016), which responds to local demands and evolves based on specific conditions and mobility cultures. Apart from jeepneys (already discussed), two indigenous transport units roam around Baclaran: pedicab and tricycle (see Figures $8 \& 9$ ). Pedicab is a human-powered rickshaw, while tricycle is a motorized vehicle. These small units carry one to four passengers.

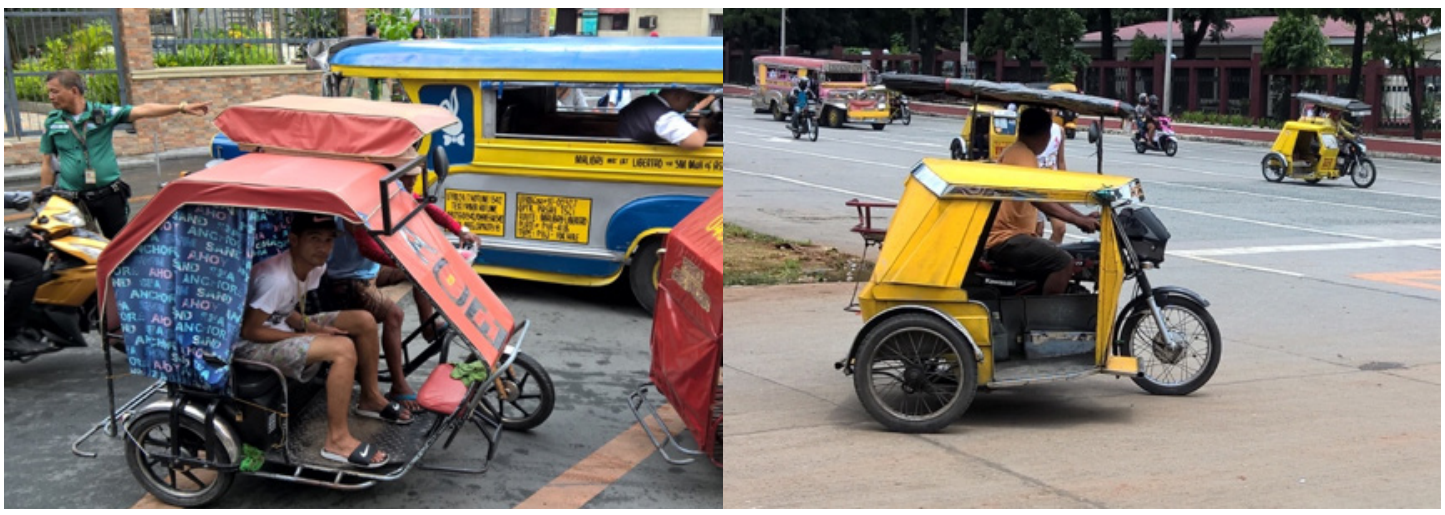

Figure 8. Pedicab

Figure 9. Tricycle

Pedicab and tricycle operators could easily navigate through the crowded or narrow streets. Due to the jeepneys' inability to get through the congested roads, these two transport modes help shoppers and hawkers move around Baclaran and the nearby areas. Arguably, the conditions generated by street vending — street shoppers, crowded roads, limited jeepneys - have allowed these transport modes to multiply in Baclaran.

Narrow local streets have also facilitated the growth of indigenous transport. In the past, Pasay residents used horse-drawn carriages to move around the city. As local official, Kaye, explained, "Pasay has been there for the last 150 years. Before, our vehicles were the tiburin, those small horse-drawn carriages. So, you can see now that in our old city [settlement areas], the streets are really narrow." The tricycles and pedicabs have now replaced tiburin as the dominant transport mode in narrow collector streets. They also pass on Taft Avenue-Quirino Road network and EDSA, which are main arterial channels in Metro Manila. This indicates how unclear road hierarchy, which was similarly seen in another informal vending district of Monumento (Recio \& Gomez, 2013), also reinforces the growth of indigenous informal transport. These realities require attention to specific conditions that sustain local transport modes. Policymakers need to determine how and to what extent these transport modes satisfy certain commuter needs and/or aggravate congestion problems. 


\section{Conclusion}

In this paper, we have sought to address the questions: What are the factors that sustain informal vending in transport hubs? How does informal vending affect urban transport nodes and land-use patterns? Using a post-dualist approach, we have analysed three interrelated factors that sustain street vending in Baclaran: a) pedestrians and commuters as captive market of hawkers; b) mixed land use and agglomeration of activities; c) multi-layered socio-spatial relations. We will now highlight four implications of these factors. First, the paper shows how understanding the trading-transport interface contributes to the evolving post-dualist discourse on urban informality. Our discussion has revealed how the factors that sustain informal trading in transport hubs are embedded in the state-sanctioned land-use plans and vendor-initiated street norms, demonstrating how the formal and informal co-produce one another and enhance the functional mix in the area.

Second, it is crucial to stress how street vending is linked to unemployment in many global South cities. The Baclaran case shows that hawkers' tenacious street presence partly stems from their economic needs. Planners must then recognize that in cities where unemployment is widespread and where poor people rely on informal livelihoods, transport terminals are not just mobility nodes; they are used as economic spaces to earn a living. We therefore acknowledge the value of seeing transport terminals and moblity interchanges as natural markets (Bhowmik, 2010) where hawkers offer goods to the commuting public. When examined out of context, many people may argue that this will aggravate bottleneck issues. Amid acute poverty, however, urban planners will need to incorporate the "natural market" lens in crafting policies and land-use plans. Indeed, the multiple roles of transport hubs as sites of economic, socio-cultural and political exchanges - where commuters converge, and hawkers make a living-undescore how socio-spatial issues should earn considerable attention in transport planning.

A third implication concerns the integral role of urban planning in crafting inclusive transport nodes and land-use patterns. Often, informality is rendered invisible in urban planning's cost-benefit calculations. Urban planning is viewed as a "neutral," technical, and rational exercise aimed at improving the conditions of cities. It intends to generate "order" by removing "disorder" or eradicating things and practices labelled as unpleasant. Yet, the process of producing order always operates within existing power relations where the dominant players define what constitutes disorder (Pratt, 2006). Similar to many global South cities, planners in Baclaran embrace a neo-liberal "world-class" city vision. As state officials and planners promote order to make the areas around Baclaran attractive to local and foreign investors, informal hawkers are perceived to be contributing to urban blight, which should be removed from the public space. The precarious condition of Baclaran vendors is therefore embedded in planning issues like gentrification and agglomeration in the age of neoliberal globalization.

Although some planning interventions discriminate against informal livelihoods, leaving the sociospatial arrangements to informal channels might also deepen the unjust power relations involving street vendors and transport stakeholders. Planning is necessary to create an enabling atmosphere with inclusive governance structures where the marginalized players like vendors can articulate their rights and aspirations. In Baclaran, an inclusive and rights-based framework for urban work is vital to recognize "the legitimacy of urban informal economies, the scope for collective management of urban resources and the social value of public space as a site for urban livelihoods" (Brown, 2017b, p. 244). This resonates with the "natural market" approach to street vending. More specifically, Brown's (2017a, pp. 80-81) proposal to consider the streets "as a place of work" and a "common-pool resource" that should "be managed for shared benefits to accrue, with defined "bundles" of rights..." is a key step in managing street vending in transport nodes.

One policy recommendation arising from the "common-pool resource" framework is the establishment of a local multi-stakeholder committee for street vending. Similar to India's multi-sectoral Town 
Vending Committee (Singh \& Kumar, 2017), such a multi-sectoral body could foster an inclusive and participatory governance at the local (city and barangay) level and ensure that the common-pool resource model will be supported by local stakeholders. The local committee should consist of representatives of vendors, transport operators, government officials, mall operators, stallholders and civil society groups in the area. The committee could identify recommendations that planning offices should consider in developing land-use plans. For instance, a potential approach is to design a time-sharing of space (Brown, 2017a) to ensure that street use for vending will not result in congestion and unrestrained commercialisation of public spaces. This time-space sharing design could also democratize the access to and control of the coveted spaces in Baclaran.

The fourth implication entails examining the trading-transport nexus beyond its spatial dimension. As presented above, socio-political ties and economic realities partly shape the spatial patterns in Baclaran. Thus, examining the trading-transport nexus also involves unpacking how the interface between "formal" and "informal" arrangements creates an uneven consumption of public space. In the transport sector, this requires determining how small-scale informal transport system develops, establishing the causal relationships between drivers and factors using quantitative measures, and assessing how policies are able or unable to keep up with the issues arising from the evolving trading-transport nexus. These are crucial themes that may inform future research undertaking.

Decisionmakers in many global South cities need to consider these four implications, along with the factors sustaining informal trading in transport hubs, in designing inclusive land-use plans. They are not only important in determining the links between urban mobility and efficient land allocation; they are critical in addressing spatial exclusion in the city. 


\section{References}

Acheampong, R. A., \& Silva, E. A. (2015). Land use-transport interaction modeling: A review of the literature and future research directions. Journal of Transport and Land Use, 8, 11-38.

Banister, D. (2008). The sustainable mobility paradigm. Transport Policy, 15(2), 73-80.

Bayat, A. (1997). Street politics: Poor people's movements in Iran. New York: Columbia University Press.

Bhowmik, S. (2010). Legal protection for street vendors. Economic and Political Weekly, December 15.

Bhowmik, S. K. (2005). Street vendors in Asia: A review. Economic and Political Weekly, May.

Bostic, R. W., Kim, A. M., \& Valenzuela Jr, A. (2016). Contesting the streets: Vending and public space in global cities. Cityscape: A Journal of Policy Development and Research, 18(1), 3-10.

Bromley, R. (2000). Street vending and public policy: A global review. International Journal of Sociology and Social Policy, 20(1/2), 1-28.

Brown, A. (2017a). Claiming the streets: Reframing property rights for the urban informal economy. In A. Brown (Ed.), Rebel streets and the informal economy: Street trade and the law (pp. 77-93). Abingdon, UK: Routledge.

Brown, A. (2017b). Emerging themes for the new legal order. In A. Brown (Ed.), Rebel streets and the informal economy: Street trade and the law (pp. 239-246). Abingdon, UK: Routledge.

Brown, A. (Ed.). (2006). Intermediate technology. Contested space: Street trading, public space, and livelihoods in developing cities. West Yorkshire, UK: ITDG Publishing.

Brown, A., \& Mackie, P. (2017). Urban informality and 'rebel streets.' In A. Brown (Ed.), Rebel streets and the informal economy: Street trade and the law (pp. 1-16). Abingdon, UK: Routledge.

Bunnell, T., \& Harris, A. (2012). Reviewing informality: Perspectives from urban Asia. International Development Planning Review, 34(4), 339-348.

Bunnell, T., Miller, M. A., Phelps, N. A., \& Taylor, J. (2013). Urban development in a decentralized Indonesia: Two success stories? Pacific Affairs, 86(4), 857-876.

Carrieri, A., \& Murta, I. (2011). Cleaning up the city: A study on the removal of street vendors from downtown Belo Horizonte, Brazil. Canadian Journal of Administrative Sciences/Revue Canadienne des Sciences de l'Administration, 28(2), 217-225.

Cervero, R. B. (2013). Linking urban transport and land use in developing countries. Journal of Transport and Land Use, 6(1), 7-24.

Davy, B. (2009). Centenary paper: The poor and the land: Poverty, property, planning. Town Planning Review, 80(3), 227-265.

Donovan, M. G. (2008). Informal cities and the contestation of public space: The case of Bogota's street vendors. Urban Studies, 45(1), 29.

DOTC (Department of Transportation and Communication). (2015). MRT 3 monthly passenger traffic per station for calendar year 2014. Retrieved from http://dotr.gov.ph/images/front/Data_Sets/ MRT3-MonthlyPassengerTrafficperStationforCY2014.xlsx

Dovey, K. (2012). Informal urbanism and complex adaptive assemblage. International Development Planning Review, 34(4), 349-368.

Dovey, K. (2016). Urban design thinking: A conceptual toolkit. London: Bloomsbury Publishing.

Duffhues, J., \& Bertolini, L. (2016). From integrated aims to fragmented outcomes: Urban intensification and transportation planning in the Netherlands. Journal of Transport and Land Use, 9(3), 15-34.

Flock, R., \& Breitung, W. (2016). Migrant street vendors in urban China and the social production of public space. Population, Space and Place, 22(2), 158-169.

Granovetter, M. (1992). Economic institutions as social constructions: A framework for analysis. Acta Sociologica, 35(1), 3-11.

Janelle, D. G. (1969). Spatial reorganization: A model and concept. Annals of the Association of American 
Geographers, 59(2), 348-364.

Lundqvist, L. (2003). Land-use and travel behavior. A survey of some analysis and policy perspectives. EJTIR, 3, 299-313.

Mateo-Babiano, I. (2016). Indigeneity of transport in developing cities. International Planning Studies, 21(2), 132-147.

McGee, T. G. (1973). Hawkers in Hong Kong: A study of planning and policy in a third world city (No. 17). Hong Kong: Center of Asian Studies, University of Hong Kong.

Meneses-Reyes, R., \& Caballero-Juárez, J. A. (2014). The right to work on the street: Public space and constitutional rights. Planning Theory, 13(4), 370-386.

Mitchell, D. (2003). The right to the city: Social justice and the fight for public space. New York: Guilford Press.

Moser, C. O., \& Lister, S. (Eds.). (1999). Violence and social capital: Proceedings of the LCSES Seminar Series, 1997-98. Washington, DC: World Bank, Latin America and the Caribbean Region, Environmentally and Socially Sustainable Development SMU.

Musoni, F. (2010). Operation Murambatsvina and the politics of street vendors in Zimbabwe. Journal of Southern African Studies, 36(2), 301-317.

Okello, D. (2017, August 4). Live bullets as angry vendors take dead colleague to KCCA. ChimpReports. Retrieved from http://www.chimpreports.com/live-bullets-as-angryvendors-take-dead-colleague-tokccal

Oriard, L. R. (2015). Street vending and its ability to produce space: The case of the Tepito market in Mexico City downtown area. Doctoral dissertation. London: University College London.

Pacheco-Raguz, J. F. (2010). Assessing the impacts of light rail transit on urban land in Manila. Journal of Transport and Land Use, 3(1), 113-138.

Peña, S. (1999). Informal markets: Street vendors in Mexico City. Habitat International, 23(3), 363372.

Phelps, N. A., Bunnell, T., Miller, M. A., \& Taylor, J. (2014). Urban inter-referencing within and beyond a decentralized Indonesia. Cities, 39, 37-49.

Porter, L. (2011). Informality, the commons and the paradoxes for planning: Concepts and debates for informality and planning. Planning Theory and Practice, 2(1), 115-120.

PSA or Philippine Statistics Authority. (2015). Retreived from https://psa.gov.ph/content/populationnational-capital-region-based-2015-census-population-0

Pratt, N. (2006). Informal enterprises and street vending: A civil society and urban management perspective. In A. Brown (Ed.), Contested wpace: Street trading, public space and livelihoods in developing cities (pp. 37-53). West Yorkshire, UK: ITDG Publishing.

Recio, R. B. (2015). Engaging the 'ungovernable': Urban informality issues and insights for planning. Journal in Urban and Regional Planning, 2(1), 18-37.

Recio, R. B. (2018). Who governs the 'ungovernable'? Examining governing relations in urban informality. Doctoral thesis. St. Lucia, Queensland, Australia: University of Queensland.

Recio, R. B., \& Gomez Jr., J. E. A. (2013). Street vendors, their contested spaces, and the policy environment: A view from Caloocan, Metro Manila. Environment and Urbanization Asia, 4(1), 173-190.

Recio, R. B., Mateo-Babiano, I., \& Roitman, S. (2017). Revisiting policy epistemologies on urban informality: Towards a post-dualist view. Cities, 61, 136-143.

Robinson, J. (2006). Ordinary cities: Between modernity and development. Abingdon, UK: Routledge. Roever, S., \& Skinner, C. (2016). Street vendors and cities. Environment and Urbanization, 28(2), 359374.

Roy, A. (2005). Urban informality: Toward an epistemology of planning. Journal of the American Plan- 
ning Association, 71(2), 147-158.

Roy, A., \& AlSayyad, N. (Eds.). (2004). Urban informality: Transnational perspectives from the Middle East, Latin America, and South Asia. Lanham, MD: Lexington Books.

Scott, A. J., \& Storper, M. (2015). The nature of cities: The scope and limits of urban theory. International Journal of Urban and Regional Research, 39(1), 1-15.

Singh, A., \& Kumar, S. (2017). Trade unions in transformation towards a better deal for street vendors in India: The Case of NASVI. Retrieved from http://library.fes.de/pdf-files/iez/13641.pdf

Song, L. K. (2016). Planning with urban informality: A case for inclusion, co-production and reiteration. International Development Planning Review, 38(4), 359-381.

Stavenhagen, R. (1965). Classes, colonialism, and acculturation. Studies in Comparative International Development, 1(6), 53-77.

Swider, S. (2015). Reshaping China's urban citizenship: Street vendors, Chengguan and struggles over the right to the city. Critical Sociology, 41(4-5), 701-716.

UN-Habitat. (2009). Planning sustainable cities: Policy directions (global report on human settlements). London: Earthscan.

Vanek, J., Chen, M. A., Carr., F., Heintz, J., \& Hussmanns, R. (2014). Statistics on the informal economy: Definitions, regional estimates and challenges. Retrieved from http://www.wiego.org/sites/default/files/ publications/files/Vanek-Statistics-WIEGOWP2.pdf

Waddell, P. (2011). Integrated land use and transportation planning and modeling: Addressing challenges in research and practice. Transport Reviews, 31, 209-229.

Wegener, M. (2004). Overview of land-use transport models. Handbook of Transport Geography and Spa-tial Systems, 5, 127-146.

Weng, C., \& Kim, A. (2016). The critical role of street vendor organizations in relocating street vendors into public markets: The case of Hsinchu City, Taiwan. Cityscape, 18(1), 47-69.

World Bank. (2013). Philippine development report. Manila: World Bank Manila Office.

Yiftachel, O. (2006). Re-engaging planning theory? Towards 'South-Eastern' perspectives. Planning Theory, 5(3), 211-222 